\title{
To study the modifications and new prospects in Kathiawar stitches on cushion cover
}

Author for Correspondence :

\section{RITU GARG}

Faculty of Home Science, Sri Ram Group of Colleges, MUZAFFARNAGAR (U.P.)

INDIA

Email : ritu77.garg@gmail.com
ABSTRACT : In our country the art of embroidery is an ancient's art and has been existing as an inheritance from one generation to the next generation. Although it has reached great heights many times but there have also been signs of its decay. Even than its importance has never been minimized to any extent. Indian embroideries are not the products of individual craft men. The first and foremost task of any research is to throw light on unknown or little known facts and figures so as to discover, explain and record accurately related past events and the status of the past phenomena. My research aims at doing the same and showing the facts related to embroideries. Research will also describe the new prospects and modifications in Kathiawar stitches. The present study is a sincere attempt of the researcher to create a product (only cushion cover) using Kathiawar embroidery and assessing its consumer acceptability according to the market trend. The traditional motifs embroidery was collected from various sources such as books, museums and artisans of Kathiawar. Twenty two motifs of Khatiawar embroidery were evaluated by judges at 2 level. The result revealed that that modern and traditional design, first preferences given by judge and students given to modern modification and when the modified sample were shown to women they also like it.

KEY WORDS: Kutch embroidery, Cushion cover

- HOW TO CITE THIS PAPER : Garg, Ritu (2016). To study the modifications and new prospects in Kathiawar stitches on cushion cover. Asian J. Home Sci., 11 (2) : 415-424, DOI: 10.15740/HAS/AJHS/ 11.2/415-424. 